\title{
Upsurge production of cellulase from maize stover under soildstate conditions mediated by Streptomyces enissocaesilis DQ026641
}

\author{
Ashok Sudarshan*, Siddanna Renuka, Sirasagar Reshma, Bhalerao Shilanjali, Dayanand Agsar \\ Department of Microbiology, Gulbarga University, Kalaburagi, Karnataka, India.
}

\section{ARTICLE INFO \\ Article history: \\ Received on: April 24, 2021 \\ Accepted on: August 15, 2021 \\ Available online: January 07, 2022}

\section{Key words:}

Maize stover, actinobacterium, cellulase, solid-state conditions and enhanced production

\begin{abstract}
Maize stover was explored as a sole substrate of carbon for the extra cellular production of cellulase under solid-state conditions by an actinobacterium, Streptomyces enissocaesilis DQ026641. The upsurge production of cellulase was optimized manually regulating important process variables such as substrate (particle size, moisture content), organism (inoculum size), physicochemical attributes $(\mathrm{pH}$, temperature) and mineral salts $\left(\mathrm{NaCl}, \mathrm{MgSO}_{4}, \mathrm{FeSO}_{4}\right.$ following one factor at a time approach. The maximum production $(71.10 \mathrm{IU} / \mathrm{ml})$ of cellulase was obtained at particle size $2 \mathrm{~mm}$, moisture content $1.25 \%$, temperature $45^{\circ} \mathrm{C}$, inoculum size $1 \times 10^{8}$ and $\mathrm{NaCl} 1.5 \%$. Enhanced production $(79 \mathrm{IU} / \mathrm{ml})$ of cellulase was achieved by following Response Surface Methodology with Centre Composite Design, considering $\mathrm{pH} 6.5$, temperature $45^{\circ} \mathrm{C}$ and sodium chloride $1.5 \%$ as critical process variables. The quadratic impact of $\mathrm{pH}$, temperature and sodium chloride significantly contributed for the production of cellulase under solid-state conditions from maize stover mediated by $S$. enissocaesilis DQ026641.
\end{abstract}

\section{INTRODUCTION}

Annually, about 960 million tons of solid waste are generated as byproducts of manufacturing, urban, agricultural, and other processes, with 350 million tons of organic waste from agricultural sources alone [1]. Bajar et al. [2] proposed that these lignocellulosic squanders, especially farming buildups, are the best carbon hotspots for the creation of microbial chemicals. Crop residues rich in cellulose account for half of the dry weight of agricultural waste. Biodegradation of cellulose is an essential aspect of the biosphere's carbon cycle [3]. Because of their higher stability and activity over a wider range of temperatures and $\mathrm{pH}$, various extremophiles such as thermophilic, alkalophilic, or acidophilic microorganisms are used as sources of thermostable and broad range of $\mathrm{pH}$ stable enzymes in the biotransformation processes [4]. Similarly, various researches were carried out to ascertain the suitability of agricultural biomass waste as alternative substrates for cellulase enzyme processing [5].

*Corresponding Author

Ashok Sudarshan, Department of Microbiology, Gulbarga University, Kalaburagi, Karnataka, India.E-mail: sudarshanashok@yahoo.com
Since cellulose accounts for up to $60 \%$ of the mass of lignocellulose, cellulases are the most important enzymatic group involved in its degradation [6]. The synthesis of cellulase enzyme was studied using a variety of solid substrates, including rice straw [7], Saw dust [8], water hyacinth [9], egg shell waste [10], wheat bran [11] and potato peel [12].

Submerged fermentation or solid-state fermentation (SSF) are currently used to produce cellulases [13]. C.W. Hesseltine was the one, who for the first time published the scientific information on solid state bioprocess in 1977. For the manufacture of microbial cellulase, solid state bioprocessing has emerged as a promising technology $[14,15]$.

Different microorganisms being used for cellulase production using solid state bioprocess viz. Aspergillus niger and Penicillium decumbans [16], Trichoderma reesei [17], T. reesei RUT C30 [18]. Dasari et al. [14] and Yoon et al. [19] reported major microorganisms employed in cellulase production via solid state bioprocess viz., Acidothermus cellulolyticus, Bacillus subtilis, Bacillus pumilus, Clostridium acetobutylicum, Clostridium thremocellum, Cellulomonas fimi, 
Cellulomonas bioazotea, Cellulomonas uda, Streptomyces drozdowiczii, Streptomyces lividans, Thermonospora fusca and Thermonospora curvata.

Response surface methodology (RSM) is the most widely used and accepted technique for optimizing the process parameters that are driven by multiple independent variables [20]. RSM is used in the optimization of a variety of products, including ethanol, bacteriocin, dye degradation, and the synthesis of enzymes such as chitinase, alkaline protease, and cellulase [21].

In the present study, efforts were made to achieve the enhanced production of cellulase enzyme under solid-state bioprocess by employing a Streptomyces enissocaesilis isolated from extreme environment of limestone quarries. Maize stover is regionally available agro-waste rich in cellulose and hence, was explored for the first time as an economic solid substrate for cellulase production by $S$. enissocaesilis.

\section{METHODOLOGY}

\subsection{Microorganism}

Streptomyces enissocaesilis DQ026641 isolated from limestone quarries of Karnataka Province, India, was used in this study. The selected isolate was identified using morphological, biochemical and 16S rRNA sequencing methods. After Polymerase Chain Reaction (PCR) amplification, purified DNA molecule fragments containing 16S rRNA genes were processed at BioEra Pvt. Ltd., Pune, for $16 \mathrm{~S}$ rRNA gene sequencing.

\subsection{Solid State Fermentation and Extraction of Crude Enzyme}

A standard protocol recommended by Idris et al. [18] was used to analyse the solid-state bioprocess. The maize stover substrate powder $(10 \mathrm{~g})$ was placed in $250 \mathrm{ml}$ Erlenmeyer flasks and moistened with sterile distilled water to achieve a moisture content of $65 \%$. The contents were sterilised before being inoculated with a $1 \mathrm{ml}$ inoculum of $S$. enissocaesilis test culture. The flasks were incubated at $35^{\circ} \mathrm{C}$ for 5 days. Using whole flasks, samples were taken every 24 hours for enzyme extraction by employing a simple contact process [22]. A total volume of $100 \mathrm{ml}$ of citrate buffer $(0.05 \mathrm{M}, \mathrm{pH} 4.8)$ was applied to the fermented substrate and mixed for 1 hour on a rotary shaker. The suspensions were filtered and centrifuged, and the supernatant was used as the crude enzyme preparation for enzyme activity assays.

\subsection{Regulation of Process Variables Affecting Cellulase Production}

Various parameters influence the cellulase production in SSF. To know the ideal conditions and impact of various parameters, the important process variables such as particle size, moisture, $\mathrm{pH}$, inoculum size, temperature and nutritional variables were regulated in different range to achieve maximum cellulase production during bioprocess.

Particles with size 1, 2, 3, 4, and $5 \mathrm{~mm}$ were used in the fermentation. Using sterile distilled water, the moisture content of the substrates was adjusted to $59.08 \%-71.28 \%$ at four levels using a moisture analyser tool. $\mathrm{pH}$ range of 4.0 to 9.0 was selected and set of five conical flasks containing fermentation media were used. Dilute $(0.1 \mathrm{~N})$ $\mathrm{NaOH} / \mathrm{HCl}$ was used to achieve the desired $\mathrm{pH}$ level. The prepared flasks were then autoclaved and inoculated with $S$. enissocaesilis spore suspension $\left(1 \times 10^{8} / \mathrm{ml}\right)$. In a static incubator, the flasks were incubated at $40^{\circ} \mathrm{C}$. The amount of cellulase generated was measured every 24 hours for a total of 120 hours incubation period. The activity of cellulase was determined at every 24 hours. Temperature range of $30^{\circ} \mathrm{C}-50^{\circ} \mathrm{C}$ was also regulated. Important mineral salts such as sodium chloride, magnesium sulphate, and ferrous sulphate were also controlled at different concentrations of $0.01 \%, 0.05 \%, 0.1 \%$, $0.15 \%$ and $0.2 \%$. Mineral salts in various concentrations, such as $\mathrm{NaCl}-0.2 \%, \mathrm{MgSO}_{4}-0.005 \%$, and $\mathrm{FeSO}_{4}-0.001 \%$, were prepared in sterile distilled water and added as moisture content.

\subsection{Assay of Endoglucanase}

The enzyme assay was performed by incubating a $1 \mathrm{ml}$ assay mixture containing $0.5 \mathrm{ml}$ crude enzyme extract and $0.5 \%$ appropriate substrate in citrate buffer $(0.5 \mathrm{ml}$ with $\mathrm{pH}-4.8)$ at $50^{\circ} \mathrm{C}$ for 30 minutes. Dinitro salicylic acid method was used to calculate the amount of reducing sugar formed [23], by spectrophotometrically measuring the absorbance at $540 \mathrm{~nm}$ and the enzyme activity was calculated.

\subsection{Statistical Optimization of Cellulase Production by RSM with (Central Composite Design) CCD}

The enhanced production of endoglucanase was carried out by RSM with CCD under solid state bioprocess system to optimize three critical process variables namely temperature $(\mathrm{A})$, sodium chloride $(\mathrm{B})$ and $\mathrm{pH}$. The Design Expert Software, USA, was used to set the CCD of 20 runs (Version 11.0). All of the experiments were performed in duplicate, and the average amount of cellulase generated after 96 hours was used as the dependent variable or response $(Y)$. The predicted response was determined using the second-degree polynomial equation, which took into account all of the terms.

$$
Y=\beta_{0}+\sum \beta_{i} X_{i}+\sum \beta_{i i} X_{i}^{2}+\sum \beta_{i j} X_{i} X_{j}
$$

where $Y$ is the response vector, $\beta_{0}$ is the intercept coefficient, $\beta_{i}$ is the linear effect coefficient, $i i$ is the quadratic effect coefficient, and $\beta_{i j}$ is the $\beta_{i j}$ th interaction coefficient effect. $X_{i} X_{j}$ are input variables that have an effect on the response variable $Y$, with $\beta_{i}$ being the $\beta_{i}$ th linear coefficient [24]. The study of variance was used to conduct the statistical and numerical analysis of the model [Analysis of Variance (ANOVA)].

Fisher's $F$-test, its related probability $p(F)$, correlation coefficient $R$, and determination coefficient $R^{2}$ were used to determine the statistical significance of the model, which describes the consistency of the polynomial model. For each variable, response surface curves were created and the quadratic models were represented as contour plots [three-dimensional (3D)].

\section{RESULTS AND DISCUSSION}

The maize stover (Fig. 1) was explored as solid-state substrate for the production of cellulase by $S$. enissocaesilis. Table 1 depicts the details of maize stover exploited for solid state bioprocess at different fermentation intervals. Maize stover was found to be an excellent natural substrate for cellulase production, which 


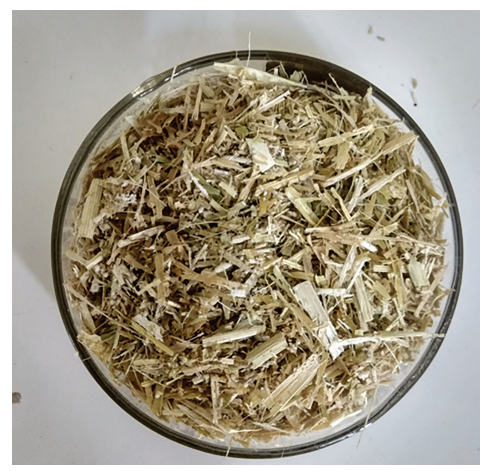

Figure 1: 1: Maize stover for the production of cellulase by S. enissocaesilis DQ026641.

yielded $35.40 \mathrm{IU} / 10 \mathrm{~g}$ of enzyme before optimization in the present study. Sinjaroonsak et al. [25] exploited Streptomyces thermocoprophilus $\mathrm{TC} 13 \mathrm{~W}$ strain and produced $925 \mathrm{U} / \mathrm{g}$ using pretreated palm oil empty bunch. Ratnakomala et al. [26] exploited Streptomyces Bse 7-9 and produced 4.499 IU using agriculture sugarcane bagasse.

\subsection{Optimization of Solid-State Bioprocess}

\subsubsection{Effect of particle size}

The test isolate with particle size ranging from $1-5 \mathrm{~mm}$ was grown in media at different fermentation period. The effect of particle size on cellulase production is shown in Figure 2. At 96 hours of fermentation period, a particle size of $2 \mathrm{~mm}$ produced the maximum cellulase with an enzyme activity (IU) of 43.20 , whereas a particle size of $5 \mathrm{~mm}$ produced the least with an enzyme activity (IU) of 22.45 .

\subsubsection{Effect of moisture content}

Enzyme activity was recorded at different moisture level ranging from $59.08 \%(1 \mathrm{ml})-71.28 \%(1.7 \mathrm{ml})$. The effect of moisture content on cellulase production is depicted in Figure 3. At 96 hours

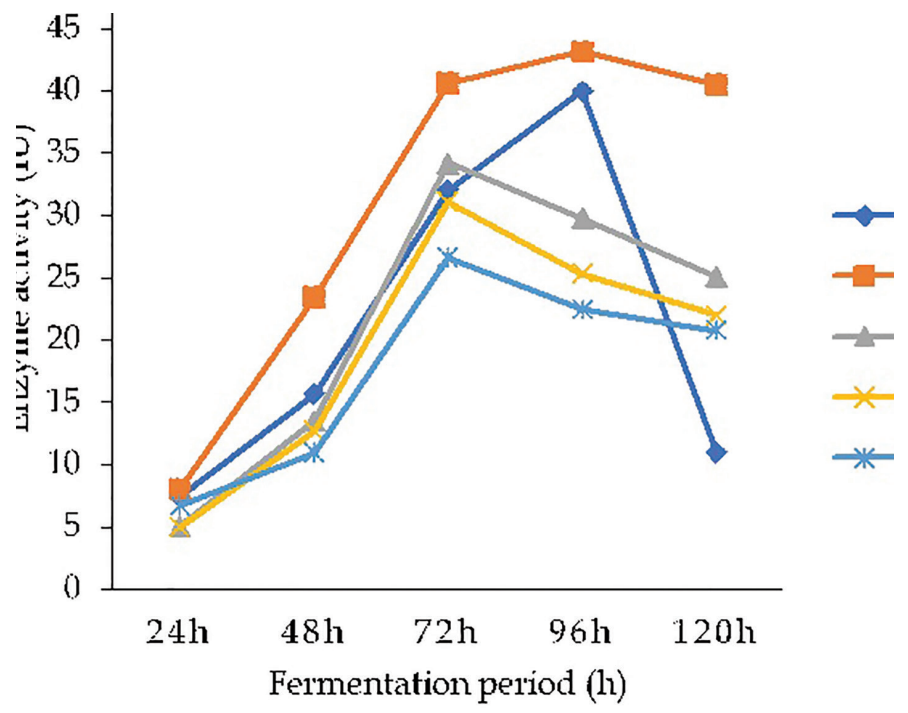

Figure 2: Effect of particle size on cellulase production at different fermentation periods by S. enissocaesilis DQ026641.
Table 1: Screening of maize stover for solid state bioprocess.

\begin{tabular}{cc} 
Fermentation period (hours) & $\begin{array}{c}\text { Enzyme activity (IU) at different } \\
\text { fermentation period }\end{array}$ \\
24 & 08.10 \\
48 & 11.00 \\
72 & 26.30 \\
96 & 35.40 \\
120 & 33.10 \\
\hline
\end{tabular}

of fermentation, a moisture content of $64.61 \%(\mathrm{w} / \mathrm{v})$ was found to be optimal for the highest production of cellulase with enzyme activity (IU) of 48.15 , and a moisture content of $2.00 \%$ was found to exhibit the least enzyme activity (IU) 30.80 . Whereas, the species such as fungi $A$. niger ITBCC L74 showed the enzyme activity of $2.569,1.606$, and $1.302 \mathrm{U} / \mathrm{ml}$, for rice straw, water hyacinth, and corn cobs respectively, at moisture content of $50 \%$, $60 \%, 70 \%$, and $80 \%$ and fermentation period of $2,4,6,8$ and 10 days [27]. Marraiki et al. [28] reported the activity of $54 \pm 2.3 \mathrm{U} / \mathrm{g}$ using Trichoderma hamatum NGL1 with $70 \%$ moisture content.

\subsubsection{Effect of $p H$}

The test isolate was grown in media of different $\mathrm{pH}$ ranging from 5-7 at different fermentation period. The effect of $\mathrm{pH}$ on cellulase production is depicted in Figure 4. At 96 hours of fermentation, a $\mathrm{pH}$ of 6.5 was found to be optimal for the highest production of cellulase, with enzyme activity (IU) 57.20, and a pH of 7.0 was found to show the least enzyme activity (IU) 30.75. Similar results were observed by El-Nahrawy et al. [29]. He showed that at higher $\mathrm{pH}$, cellulase production was greatly reduced and maximum cellulase production was observed at $\mathrm{pH}$ 6.0. According to Kshirsagar et al. [30], the highest CMCase activity was 2.38 $\mathrm{U} / \mathrm{g}$, at optimized conditions of $2.5 \mathrm{~g}$ of substrate, $75 \%(\mathrm{w} / \mathrm{w})$ moisture content, initial medium $\mathrm{pH} 4.5,1 \times 10^{6}$ spores $/ \mathrm{ml}$ of inoculum, and incubation at ambient temperature $\left(30^{\circ} \mathrm{C}\right)$ without additional carbon and nitrogen.

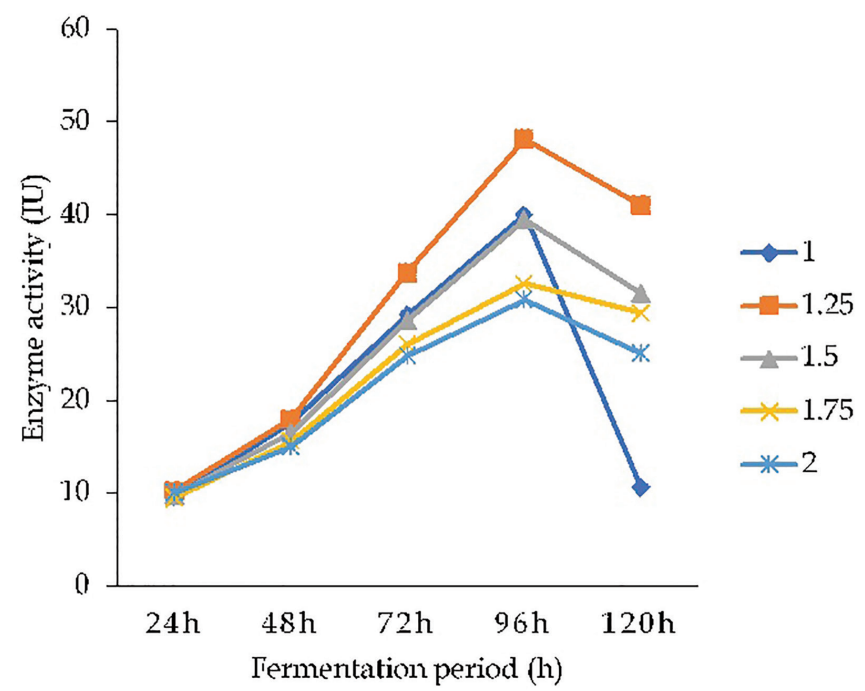

Figure 3: Effect of moisture on cellulase production at different fermentation periods by $S$. enissocaesilis DQ026641. 


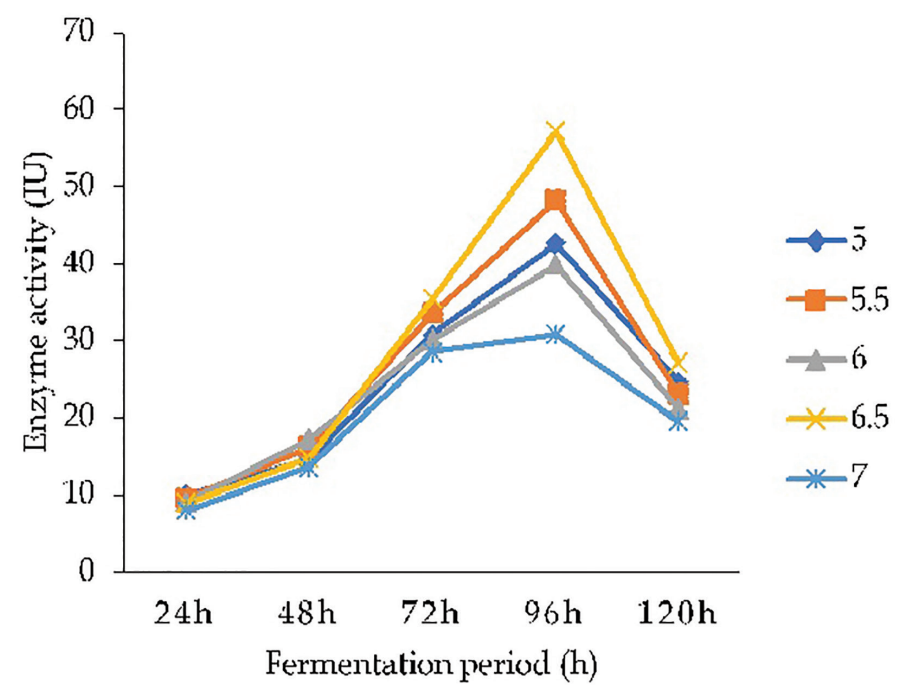

Figure 4: Effect of $\mathrm{pH}$ on cellulase production at different fermentation periods by $S$. enissocaesilis DQ026641.

\subsubsection{Effect of inoculum size}

The test isolate with inoculum size ranging from $1 \times 10^{5}-1 \times 10^{9}$ was grown in media at different fermentation period. Figure 5 represents the effect of inoculum size on cellulase production. At 96 hours of fermentation, an inoculum size of $1 \times 10^{8}$ spores $/ \mathrm{ml}$ was found to be optimal for the highest output of cellulase with enzyme activity (IU) 58.60, and an inoculum size of $1 \times 10^{5}$ spores $/ \mathrm{ml}$ was found to show the lowest enzyme activity (IU) 38.00. This was in line with the findings of Kaur et al. [31], who used the fungus Humicola fuscoatra Microbial Type Culture Collection and Gene Bank (MTCC) 140 to produce maximum cellulase under solid state fermentation with an inoculum size of $1 \times 10^{7}$ spores $/ \mathrm{ml}$.

\subsubsection{Effect of temperature}

Enzyme activity was recorded at different temperatures ranging from $30^{\circ} \mathrm{C}-50^{\circ} \mathrm{C}$. Figure 6 represents the effect of temperature on

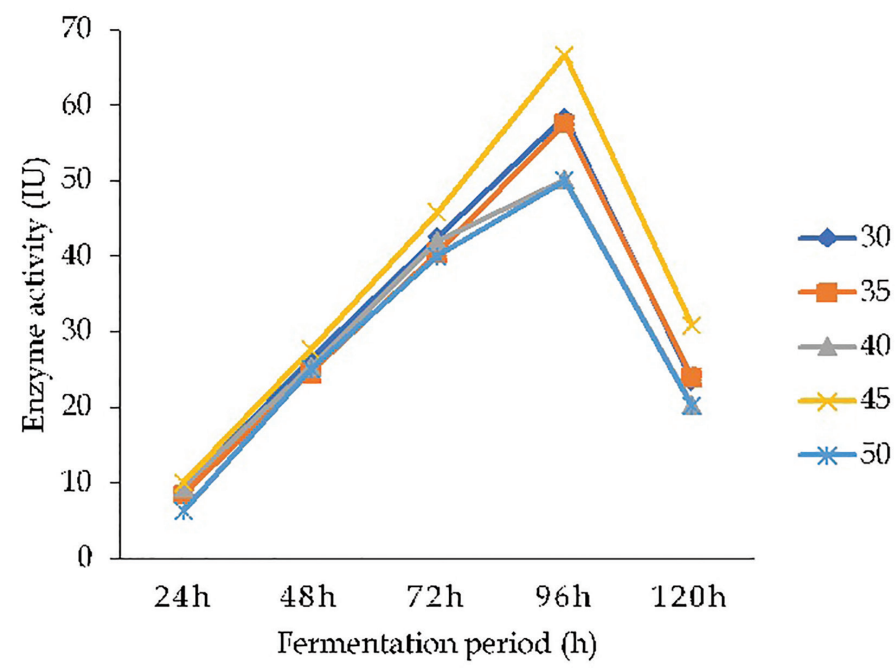

Figure 6: Effect of temperature on cellulase production at different fermentation periods by $S$. enissocaesilis DQ026641.

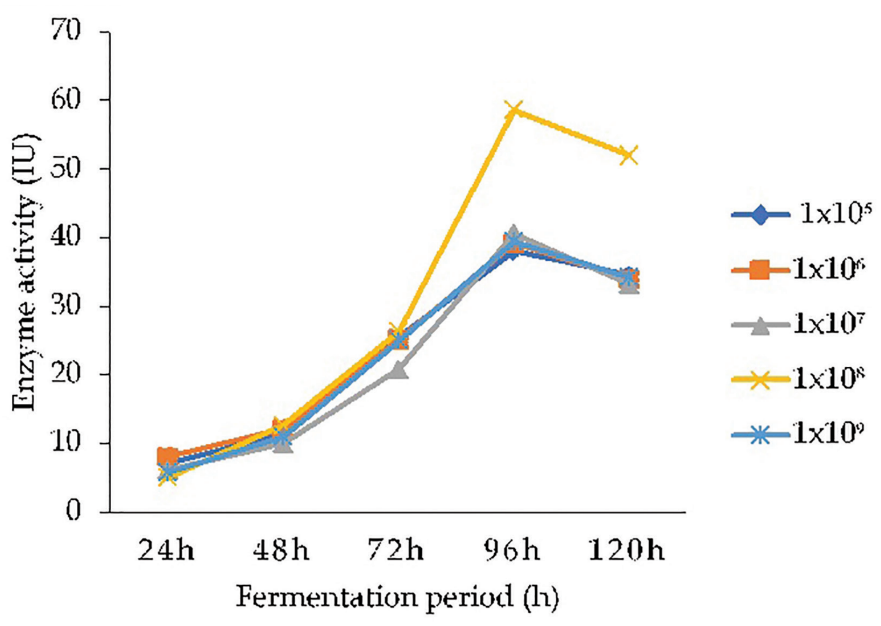

Figure 5: Effect of inoculum size on cellulase production at different fermentation periods by S. enissocaesilis DQ026641.

cellulase production. At 96 hours of fermentation, a temperature of $45^{\circ} \mathrm{C}$ was found to be optimal for the highest production of cellulase, with enzyme activity (IU) of 66.65 and the lowest enzyme activity (IU) of 50.00 was recorded with the temperature of $50^{\circ} \mathrm{C}$ at 96 hours. The requirement of high temperature for cellulase production may be attributed to the indigenous property of the strain as it was isolated from harsh environment. At $40^{\circ} \mathrm{C}$, inoculum size 0.6/100 ml, and a 96-hour incubation time, Akurathi and Thoti [32] increased enzyme activity efficiency. Kshirsagar et al. [30] found that enzyme activity was $13.91 \pm 0.89$ at a temperature of $30^{\circ} \mathrm{C}$ and a $\mathrm{pH}$ of 6.5 using corn straw and the cellulase activity after 6 days decreased. This was also in the justification of the present study.

\subsubsection{Effect of Mineral salts}

Utilization of various mineral supplements namely Magnesium sulphate, Ferrous sulphate and Sodium chloride are used at

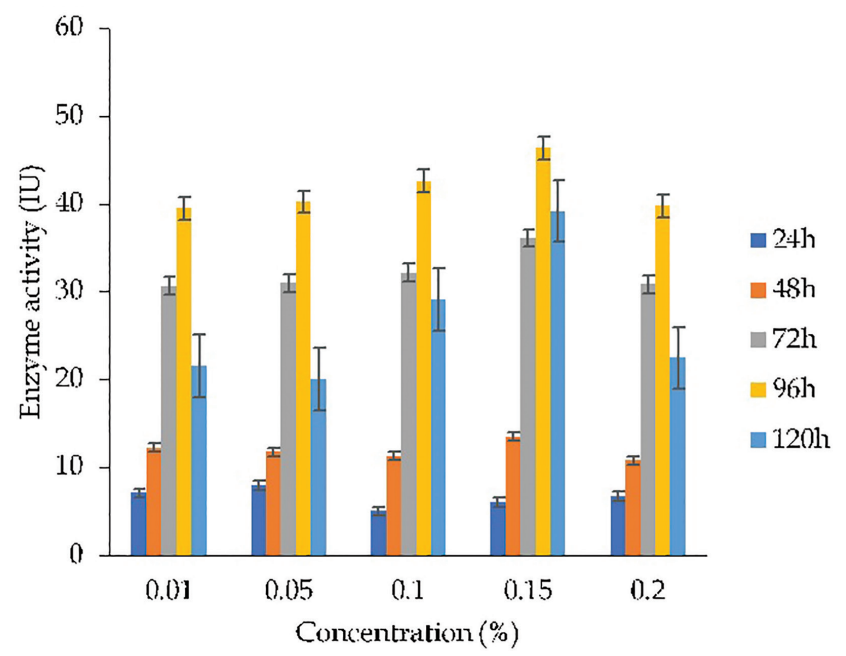

Figure 7: Effect of Magnesium sulphate on cellulase production at different fermentation periods by $S$. enissocaesilis DQ026641. 


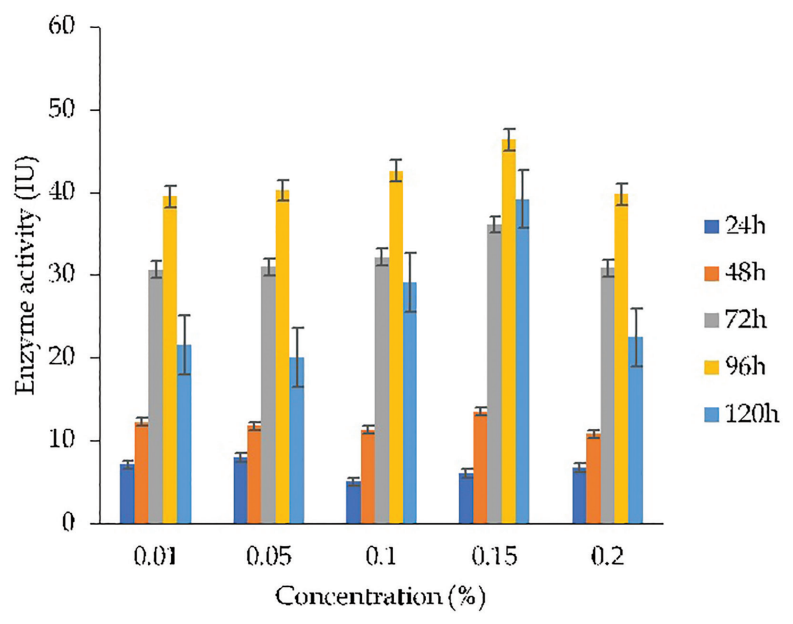

Figure 7: Effect of Magnesium sulphate on cellulase production at different fermentation periods by S. enissocaesilis DQ026641.

different concentrations in Carboxy Methyl Cellulose Beef Extract Medium (CMC BeM) media for the production of cellulase and are illustrated from Figures 7 to 9 .

At 96 hours of fermentation, concentrations of $0.15 \%$ were found to be optimal for the highest production of cellulase, with enzyme activity (IU) of 46.35 for Magnesium sulphate and 71.10 for Sodium chloride. At 96 hours of fermentation, a concentration of $0.10 \%$ was found to be optimal for the highest output of cellulase with enzyme activity (IU) 35.10 using Ferrous sulphate.

Figure 10 depicts the results of optimising the concentrations of all carbon sources used in the study for cellulase production. At optimised conditions, sodium chloride was found to be an excellent source for cellulase production, with enzyme activity (IU) 71.10, while ferrous sulphate had the least cellulase production with enzyme activity (IU) 35.10 at optimized conditions.

Sodium chloride was discovered to be an excellent source for cellulase production in this study showing enzyme activity (IU)

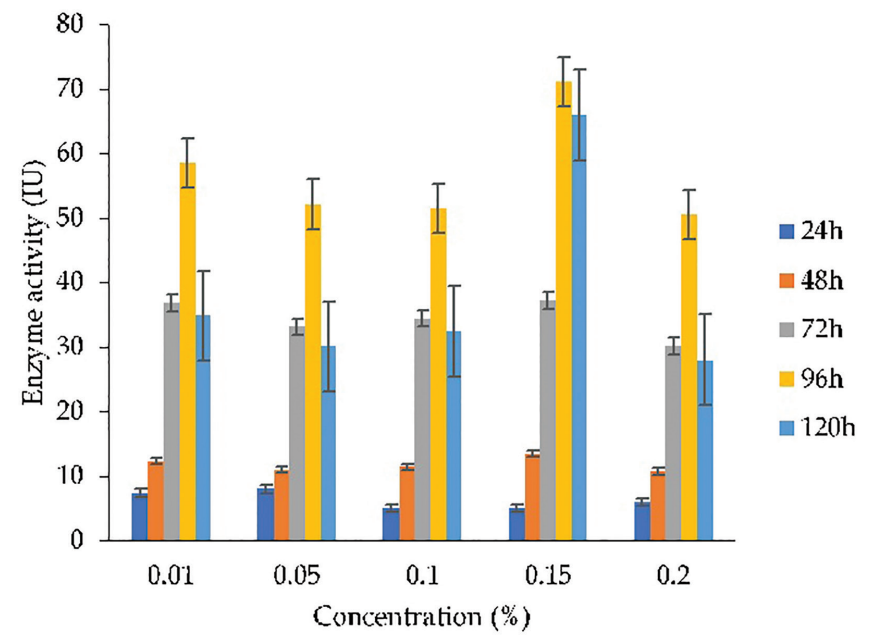

Figure 9: Effect of Sodium chloride on cellulase production at different fermentation periods by $S$. enissocaesilis DQ026641.

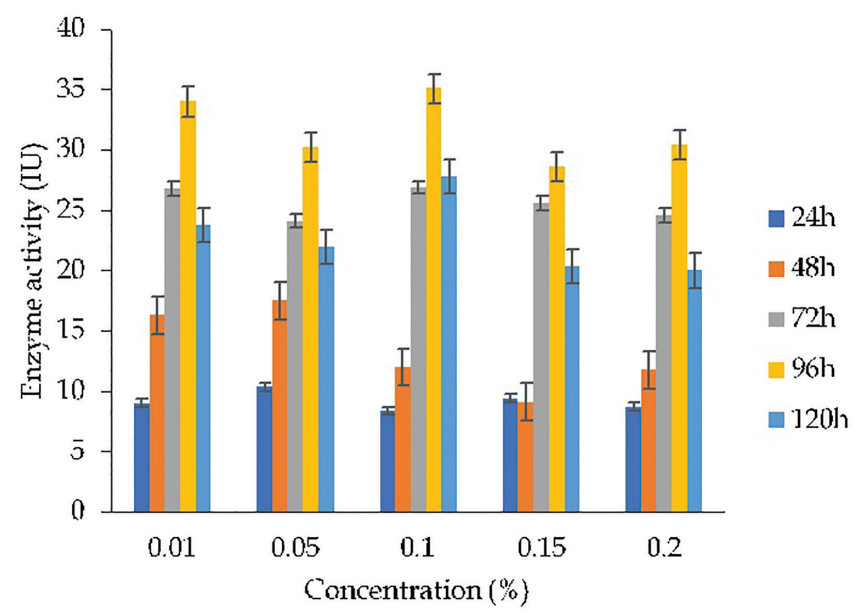

Figure 8: Effect of Ferrous sulphate on cellulase production at different fermentation periods by $S$. enissocaesilis DQ026641.

71.10 at the optimized conditions revealing the alkalophilic nature of S. enissocaesilis DQ026641 which needed high sodium chloride concentration level and high alkaline conditions for its growth. Similar observations were made by Stalin et al. [33]. In marine actinomycete, maximum enzyme activity was observed at high alkaline conditions of $\mathrm{pH} 8-10$, temperature $40^{\circ} \mathrm{C}-60^{\circ} \mathrm{C}$, and sodium chloride concentration $2 \%-4 \%$. In T. hamatum NGL1, maltose induced cellulase production [28] and in Aspergillus hortai, lactose induced cellulase production [34].

\subsubsection{Enhanced production using RSM}

Identification of the optimized condition is critically needed for maximum cellulase production. Optimization of variables showed that, $\mathrm{pH}$ of 6.5 , inoculum size of $1 \times 10^{8}$, temperature of $45^{\circ} \mathrm{C}, \mathrm{NaCl}$ and $\mathrm{MgSO}_{4}$ of concentration 0.15 and $\mathrm{FeSO}_{4}$ of 0.10 concentration was found to be optimum. Considering the high amount of cellulase production, $\mathrm{pH}$, temperature, and $\mathrm{NaCl}$ were identified as critical variables among all the optimised variables.

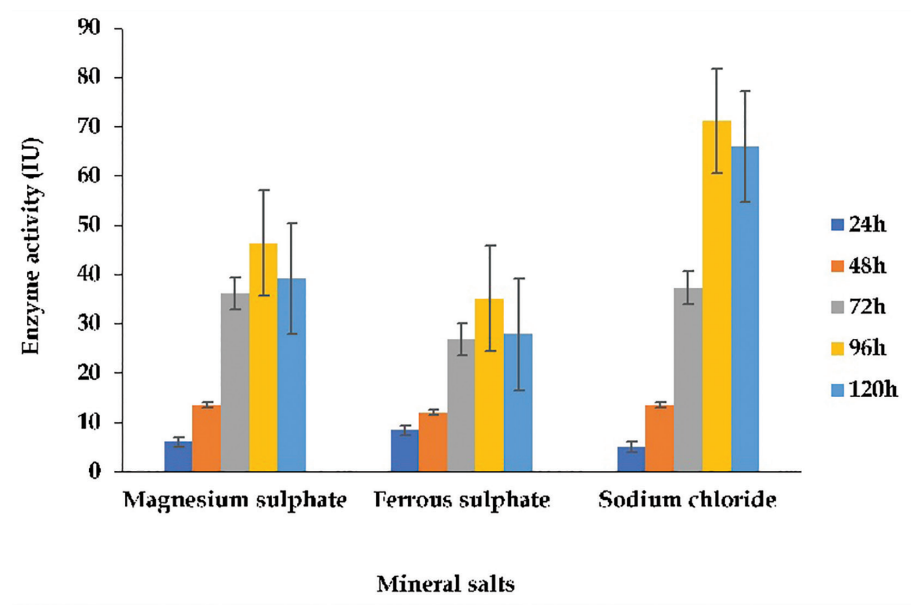

Figure 10: Effect of optimized concentrations of all mineral salts on cellulase production at different fermentation periods by $S$. enissocaesilis DQ026641. 
A

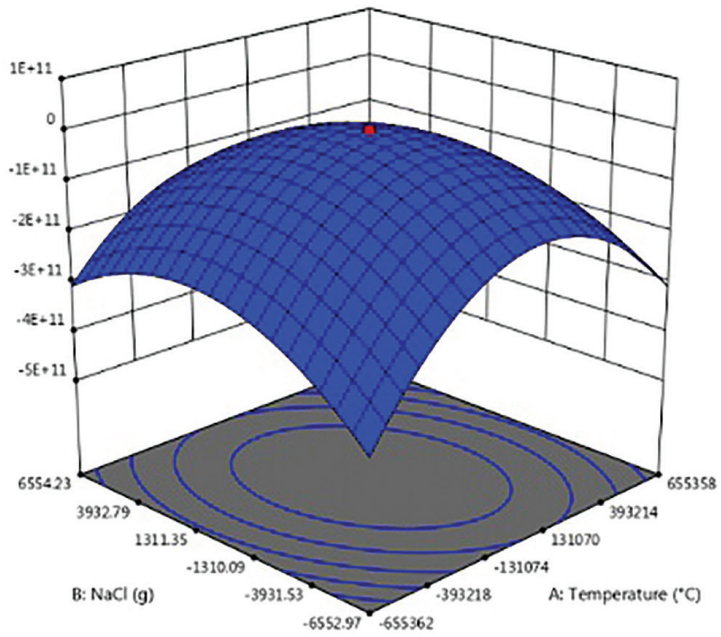

B

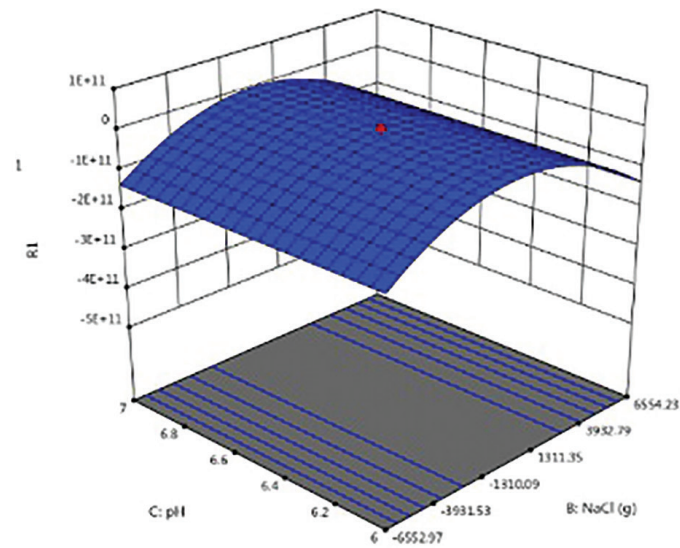

C

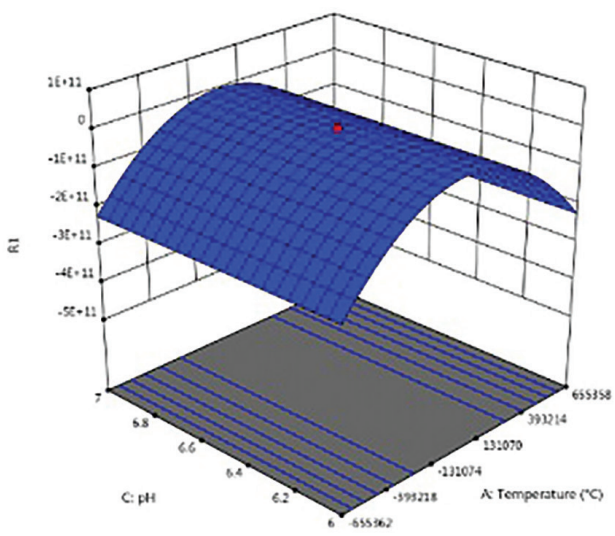

Figure 11: Response surface plots of the interactive effects: A, interaction between $\mathrm{NaCl}$ and temperature; $\mathrm{B}$, interaction between $\mathrm{pH}$ and $\mathrm{NaCl} ; \mathrm{C}$, interaction between $\mathrm{pH}$ and temperature.
The combined effect of physicochemical and nutritional variables on cellulase production was studied using RSM and CCD for the purpose of developing a suitable bioprocess. Table 2 depicts the details of combined effect of critical process variables for the production of cellulase showing the actual and predicted responses for different combinations of the critical parameters. In the second run, the highest enzyme activity was $79 \mathrm{IU} / \mathrm{ml}$ (Table 2), confirming RSM's prediction of cellulase activity of $74.61 \mathrm{IU} / \mathrm{ml}$.

The interaction effects of critical variables such as $\mathrm{pH}$, temperature, and $\mathrm{NaCl}$ for producing the highest cellulase activity were plotted using response surface curves. The interactive effects of $\mathrm{pH}$, temperature, and $\mathrm{NaCl}$ on cellulase production by $S$. enissocaesilis DQ026641 are depicted in 3D response surface plots in Figure 11(A-C).

Table 3 depicts the ANOVA of the quadratic model showing the quantitative effect of individual variables as well as their interactions affecting the activity of cellulase. The model's higher $F$-value is important since the $p$-value is 0.0001 , which is much lower than 0.5 . The important model terms in this case are $A, B$, $C, A^{2}$ and $B^{2}$. The $F$-value of 284.04 indicates that the lack of fit is significant. There's just a $0.01 \%$ risk that a significant lack of fit $F$-value is caused by noise. The quadratic effect of temperature,

Table 2: Combined effect of critical process variables for the production of cellulase.

\begin{tabular}{|c|c|c|c|c|c|}
\hline \multirow[t]{2}{*}{ Run } & \multicolumn{3}{|c|}{ Critical process variables } & \multicolumn{2}{|c|}{ Cellulase activity (IU) } \\
\hline & Temperature ${ }^{\circ} \mathrm{C}$ & $\mathrm{NaCl}$ g/l & pH & $\begin{array}{l}\text { Actual } \\
\text { value }\end{array}$ & $\begin{array}{l}\text { Predicted } \\
\text { value }\end{array}$ \\
\hline 1 & 40 & 2.0 & 6 & 55 & 58.51 \\
\hline 2 & 45 & 1.5 & 7.34 & 79 & 74.61 \\
\hline 3 & 36.59 & 1.5 & 6.5 & 48 & 46.97 \\
\hline 4 & 45 & 2.3 & 6.5 & 66 & 54.54 \\
\hline 5 & 40 & 2.0 & 7.0 & 60 & 66.31 \\
\hline 6 & 45 & 1.5 & 6.5 & 70 & 70.55 \\
\hline 7 & 50 & 2.0 & 7.0 & 35 & 41.33 \\
\hline 8 & 45 & 1.5 & 5.65 & 58 & 57.30 \\
\hline 9 & 40 & 1.0 & 6.0 & 42 & 39.27 \\
\hline 10 & 45 & 0.7 & 6.5 & 36 & 42.36 \\
\hline 11 & 45 & 1.5 & 6.5 & 71 & 70.55 \\
\hline 12 & 45 & 1.5 & 6.5 & 70.05 & 70.55 \\
\hline 13 & 45 & 1.5 & 6.5 & 70.5 & 70.55 \\
\hline 14 & 50 & 1.0 & 7.0 & 46 & 46.09 \\
\hline 15 & 45 & 1.5 & 6.5 & 71 & 70.55 \\
\hline 16 & 50 & 2.0 & 6.0 & 35 & 41.03 \\
\hline 17 & 40 & 1.0 & 7.0 & 62 & 59.57 \\
\hline 18 & 50 & 1.0 & 6.0 & 36 & 33.29 \\
\hline 19 & 45 & 1.5 & 6.5 & 69.9 & 70.55 \\
\hline 20 & 53.40 & 1.5 & 6.5 & 25 & 20.94 \\
\hline
\end{tabular}




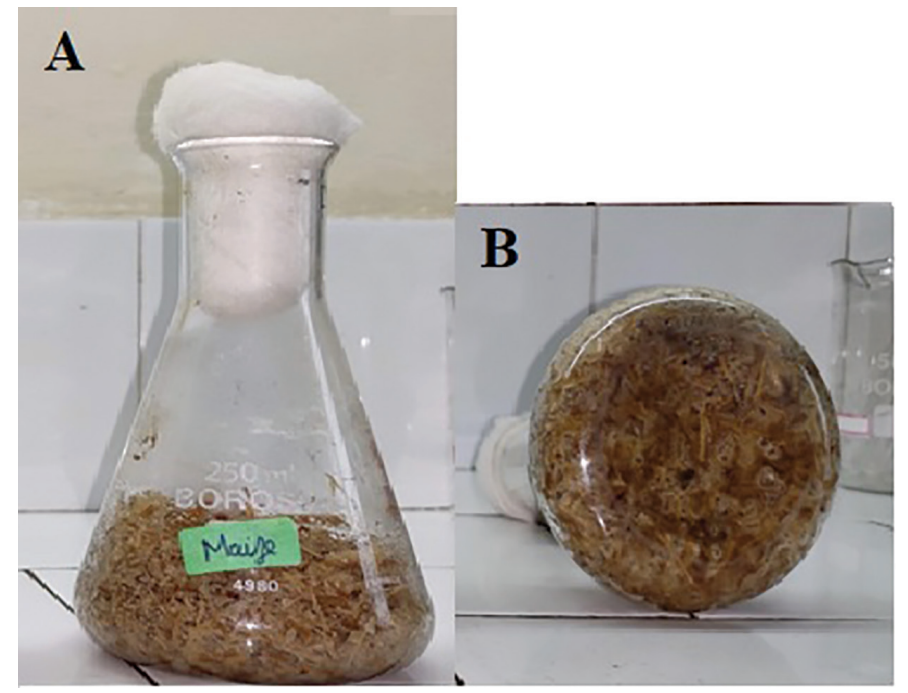

Figure 12: Production of cellulase from maize stover by solid state bioprocess: A, Sideview of the flask; B, Bottom view of the flask.

$\mathrm{NaCl}$ and $\mathrm{pH}$ was significantly contributing to cellulase production in S. enissocaesilis DQ026641.

Results showed that $S$. enissocaesilis is viable and highest cellulase producer at thermophilic and alkalophilc conditions compared to other organisms under extreme conditions by using RSM [35]. Using an optimization technique, Tai et al. [36] increased CMCase production from 2.55 to $124.5 \mathrm{U} / \mathrm{g}$. Other researchers also enhanced cellulase production using RSM prediction $[37,38]$.

\subsubsection{Mechanism of action of S. enissocaesilis DQ026641}

Herbivores lack the enzymatic capacity needed to degrade plant polysaccharides, particularly cellulose and instead depend on microorganisms which have this ability. The cellulose fermenting microbes survive by degrading insoluble polymers in highly competitive and nitrogen poor environment [39]. Several studies have examined the degradation of cellulose using various cellulolytic microorganisms [40].

In the present study, maize stover was used as a model feedstock to test the efficacy of Streptomyces cellulase for hydrolysis of lignocellulose. Figure 12 visual observations of cellulase production under solid-state bioprocess by $S$. enissocaesilis DQ026641. Streptomyces enissocaesilis uses sec secretion system. Generally, three types of glycosyl hydrolases namely Endoglucanases (EG; EC 3.2.1.4), Cellobiohydrolases (CBH, EC 3.2.1.91) and $\beta$-glucosidases (BG, EC 3.2.1.21) are responsible for the conversion of cellulose into glucose. Endoglucanases randomly break the internal bonds of the amorphous structure of cellulose. Cellobiohydrolases acts primarily on the crystalline portion and catalyses the release of glucose or cellobiose from the ends of the cellulose fibre. $\beta$-glucosidases act on oligosaccharides and disaccharides, catalyses the release of glucose [41].

The method of action and substrate specificities of different cellulases varies [42]. In actinomycete, cellulase are free and secreted extracellularly using specific secretion pathway.
Table 3: ANOVA for quadratic model.

\begin{tabular}{lccccc} 
Source & $\begin{array}{c}\text { Sum of } \\
\text { squares }\end{array}$ & df & $\begin{array}{c}\text { Mean } \\
\text { square }\end{array}$ & $\boldsymbol{F}$-value & $\boldsymbol{p}$-value \\
Model & $4,565.54$ & 9 & 507.28 & 14.10 & 0.0001 \\
$A$-temperature & 817.80 & 1 & 817.80 & 22.73 & 0.0008 \\
$B$-NaCl & 179.08 & 1 & 179.08 & 4.98 & 0.0497 \\
$C$-pH & 362.06 & 1 & 362.06 & 10.06 & 0.0099 \\
$A B$ & 66.13 & 1 & 66.13 & 1.84 & 0.2050 \\
$A C$ & 28.13 & 1 & 28.13 & 0.7818 & 0.3973 \\
$B C$ & 78.13 & 1 & 78.13 & 2.17 & 0.1713 \\
$A^{2}$ & $2,412.99$ & 1 & $2,412.99$ & 67.08 & $<0.0001$ \\
$B^{2}$ & 879.76 & 1 & 879.76 & 24.46 & 0.0006 \\
$C^{2}$ & 38.10 & 1 & 38.10 & 1.06 & 0.3276 \\
Residual & 359.74 & 10 & 35.97 & & \\
Lack of fit & 358.48 & 5 & 71.70 & 284.04 & $<0.0001$ \\
Pure error & 1.26 & 5 & 0.2524 & & \\
Cor total & $4,925.28$ & 19 & & & \\
\hline
\end{tabular}

Actinomycetes release extracellular cellulases by one or both of the common bacterial systems for extracellular protein secretion, namely the sec general secretion system and the sec independent twin arginine translocation systems. [43].

The investigation described above suggests that, in controlled laboratory conditions the cellulose is completely hydrolysed using S. enissocaesilis. Being thermoalkalophilic, it produces cellulase enzyme which is withstand high comparatively temperatures and alkaline conditions with respect to the cellulase produced by other cellulolytic microorganisms $[30,32]$.

\section{CONCLUSIONS}

In the present study, efforts were made to increase the enzyme production at thermoalkalophilic conditions of SSF medium. The results revealed that cellulase activity of $79 \mathrm{IU} / \mathrm{ml}$ under optimised conditions by S. enissocaesilis DQ026641 is better than other reported strains. Herein, we report for the first time to our knowledge the increased production of cellulase by thermoalkalophilic Streptomyces sp. isolated from harsh environment of limestone quarries. this thermotolerant species will have more important biotechnology applications due to its ability to produce thermostable cellulase and even reduces the risk of contamination by mesophilic microorganisms.

\section{ACKNOWLWDGEMENTS}

The authors like to acknowledge Gulbarga University, Kalaburagi for providing financial support to Mr. Sudarshan A in terms of studentship.

\section{AUTHOR CONTRIBUTIONS}

All authors made substantial contributions to conception and design, acquisition of data, or analysis and interpretation of data; took part in drafting the article or revising it critically for important intellectual content; agreed to submit to the current journal; gave final approval of the version to be published; and 
agree to be accountable for all aspects of the work. All the authors are eligible to be an author as per the international committee of medical journal editors (ICMJE) requirements/guidelines.

\section{CONFLICTS OF INTEREST}

Authors would hereby like to declare that there is no conflict of interests that could possibly arise.

\section{ETHICAL APPROVALS}

This study does not involve experiments on animals or human subjects.

\section{REFERENCES}

1. Ramasubramani R, Gunasekaran K. Sustainable alternate materials for concrete production from renewable source and waste. Sustainability 2021;13(3):1204; doi:10.3390/su13031204

2. Bajar S, Singh A, Bishnoi NR. Exploration of low-cost agro-industrial waste substrate for cellulase and xylanase production using Aspergillus heteromorphus. Appl Water Sci 2020;10; doi:10.1007/s13201-02001236-w

3. Sudarshan A, Renuka S, Talwar S, Reshma S, Shilanjali B, Agsar D. Detection, screening and molecular characterization of potential actinobacterium from lime-dwelling powder for extra cellular cellulase. Int J Res Appl Sci Biotechnol 2021; doi:10.31033/ijrasb.8.1.11

4. Thiruvengadam S, Subbiah S, Chellapandian B, Arunachalam C, Omaima N, Sulaiman A, et al. Purification and characterization of carboxymethylcellulase from Bacillus pumilus EWBCM1 isolated from earthworm gut (Eudrilus eugeniae) J King Saud Univ Sci 2021;33(1); doi:10.1016/j.jksus.2020.101261.

5. Kalsoom R, Ahmed S, Nadeem M, Chohan S, Abid M. Biosynthesis and extraction of cellulase produced by Trichoderma on agro-wastes. Int J Environ Sci Technol 2019;16:921-8;doi:10.1007/s13762-0181717-8.

6. Mesbah NM, Wiegel JA. Halophilic, alkalithermostable, ionic liquidtolerant cellulase and its application in in situ saccharification of rice straw. Bioenergy Res 2017;10:583-91; doi:10.1007/s12155-0179825-8.

7. Hideno A. thermogravimetric analysis-based characterization of suitable biomass for alkaline peroxide treatment to obtain cellulose and fermentable sugars. BioResources 2020;15(3):6217-29.

8. Guruchandran V, Sasikumar C. Cellulase production by Aspergillus niger fermented in sawdust and bagasse. J Cell Tissue Res 2010;10:2115-7.

9. Zhao SH, Liang XH, Hua DL, Ma TS, Zhang HB. High yield cellulose production in solid state fermentation by Trichoderma reesei SEMCC - 3.217 using water hyacinth (Eichhornia Crassipes). Afr J Biotech 2011;10(50):10178-87.

10. Verma N, Kumar V, Bansal MC. Valorisation of waste biomass in fermentative production of cellulases: a review. Waste Biomass Valor 2021;12:613-40; doi:10.1007/s12649-020-01048-8.

11. Verma N, Kumar V. Impact of process parameters and plant polysaccharide hydrolysates in cellulase production by Trichoderma reesei and Neurospora crassa under wheat bran based solid state fermentation. Biotechnol 2020;25:e00416.

12. Dos Santos TC, Gomes DPP, Bonomo RCF. Optimisation of solidstate fermentation of potato peel for the production of cellulolytic enzyme. Food Chem 2012;133:1299-304.

13. Ruchi A, Amit V, Reeta RS, Sunita V, Cheng DD, Anil KP. Current understanding of the inhibition factors and their mechanism of action for the lignocellulosic biomass hydrolysis. Bioresour Technol 2021;332; doi:10.1016/j.biortech.2021.125042.

14. Dasari PR, Ramteke PW, Kesri S, Kongala PR. comparative study of cellulase production using submerged and solid-state fermentation. In:
Srivastava M, Srivastava N, Ramteke P, Mishra P (eds.). approaches to enhance industrial production of fungal cellulases. Fungal biology Springer, Cham, Switzerland, 2019; doi:10.1007/978-3-030-1472663 .

15. Hatice P, Didem T, Halide A. Production and characterization of lipase from Penicillium aurantiogriseum under solid-state fermentation using sunflower pulp. Biocatal Biotransform 2021; doi:10.1080/102 42422.2021.1901888

16. Maurice, N. Role of solid-state fermentation to enhance cellulase production. New and Future Dev Microb Biotechnol Bioeng 2019:127-53; doi:10.1016/b978-0-444-64223-3.00009-6.

17. Rocha LM, Campanhol BS, Bastos RG. Solid-state cultivation of Aspergillus niger-Trichoderma reesei from sugarcane bagasse with vinasse in bench packed-bed column bioreactor; doi:10.21203/ rs.3.rs-158166/v1. PPR:PPR280151.

18. Idris ASO, Pandey A, Rao SS, Sukumaran RK. Cellulase production through solid-state tray fermentation, and its use for bioethanol from sorghum stover. Bioresour Technol 2017;242:265-71.

19. Yoon LW, Ang TN, Ngoh GC, Chua ASM. Fungal solid-state fermentation and various methods of enhancement in cellulase production. Biomass Bioenergy 2014;67:319-38.

20. Sharma M, Kumar BB. Optimization of bioprocess variables for production of a thermostable and wide range $\mathrm{pH}$ stable carboxymethyl cellulase from Bacillus subtilis MS 54 under solid state fermentation. Environ Prog Sustain Energy 2017;36:1123-30; doi:10.1002/ep.12557

21. Shankar T, Isaiarasu. Cellulase production by Bacillus pumilus EWBCM1 under varying cultural conditions. Middle-East J Sci Res 2011;8(1):40-5.

22. Singhania RR, Sukumaran RK, Patel AK, Larroche C, Pandey A. Advancement and comparative profiles in the production technologies using solid-state and submerged fermentation for microbial cellulases. Enzyme Microbial Technol 2010;46:541-49.

23. Miller GL, Use of dinitro salicylic acid reagent for determination of reducing sugar. Anal Chem 1959;31:426-8.

24. Nkodi MT, Mulaji KC, Mabela MR, Kayembe SJ, Biey ME, Ekoko G, et al. Investigation of factors affecting biogas production from cassava peels by fractional factorial design experimental methodology. J Appl Life Sci Int 2020;23(2):49-56; doi:10.9734/jalsi/2020/v23i230146

25. Sinjaroonsak S, Chaiyaso T, Aran H. Optimization of cellulase and xylanase productions by Streptomyces thermocoprophilus TC13W using low cost pretreated oil palm empty fruit bunch. Waste Biomass Valori 2019; doi:10.1007/s1264 9-019-00720-y.

26. Ratnakomala S. Enhancement of cellulase (CMCase) production from marine actinomycetes Streptomyces sp. Bse 7-9: optimization of fermentation medium by response surface methodology. IOP Conf Ser Earth Environ Sci 2019;251(2019):012005.

27. Abdullah B, Maftukhah S, Listyaningrum E, Faradhiba F. Effect of some variable in cellulase production by Aspergillus niger ITBCC L74 using solid state fermentation. IOP Conf. Ser Mater Sci Eng 2018;316(2018):012066; doi:10.1088/1757-899X/316/1/012066.

28. Marraiki N, Vijayaraghavan P, Elgorban AM, Dhas DSD, Al-Rashed S, Yassina MT. Low-cost feedstock for the production of endoglucanase in solid state fermentation by Trichoderma hamatum NGL1 using response surface methodology and saccharification efficacy. J King Saud Univ Sci 2020;32:1718-24; doi:10.1016/j.jksus.2020.01.008

29. El-Nahrawy S, Metwally M, El-Kodoos RYA, Belal EB, Shabana SA, El-Refai M. Optimization of culture conditions for production of cellulase by Aspergillus tubingensis KY615746 using rice straw waste. Environ Biodivers Soil Secur 2017;1:177-89.

30. Kshirsagar SD, Saratale GD, Saratale RG, Govindwar SP, Oh MK. An isolated Amycolatopsis sp. GDS for cellulase and xylanase production using agricultural waste biomass. J Appl Microbiol 2016;120(1):11225; doi:10.1111/jam.12988.

31. Kaur B, Bhatia S, Phutela U. Production of cellulases from Humicola fuscoatra MTCC 1409: role of enzymes in paddy straw digestion. Afr J Microb Res 2015;9:631-8. 
32. Akurathi R, Thoti D. Biocatalysis of agro-processing waste by marine Streptomyces fungicidicus strain RPBS-A4 for cellulase production. J Appl Biol Biotechnol 2018;6(1):38-42.

33. Stalin T, Priya SB, Selvam K. Ecofriendly application of cellulase and xylanase producing marine Streptomyces clavuligerus as enhancer in biogas production from waste. Afr J Environ Sci Technol 2012;6(6):258-62.

34. El-Hadi AA, El-Nour SA, Hammad A, Kamel Z, Anwar M. Optimization of cultural and nutritional conditions for carboxymethyl cellulase production by Aspergillus hortai. J Radiat Res Appl Sci 2014;7:23-8.

35. Shajahan S, Moorthy IG, Sivakumar N, Selvakumar G. Statistical modeling and optimization of cellulase production by Bacillus licheniformis NCIM 5556 isolated from the hot spring, Maharashtra, India. J King Saudi Univ Sci 2017;29:302-10.

36. Tai WY, Tan JS, Lim V, Lee CK. Comprehensive studies on optimization of cellulase and xylanase production by a local indigenous fungus strain via solid state fermentation using oil palm frond as substrate. Biotechnol Prog 2019:e2781; doi:10.1002/btpr.2781

37. Maravi P, Kumar A. Optimization and statistical modeling of microbial cellulase production using submerged culture. J App Biol Biotech 2021;9(2):142-52; doi:10.7324/JABB.2021.9213

38. Ahmad T, Sharma A, Gupta G, Mansoor S, Jan S, Kaur B, et al. Response surface optimization of cellulase production from Aneurinibacillus aneurinilyticus BKT-9: an isolate of urban Himalayan freshwater. Saudi J Biol Sci 2020;27:2333-43.

39. Bao Y, Dolfing J, Guo Z, Chen R, Wu M, Li Z, et al. Important ecophysiological roles of non-dominant Actinobacteria in plant residue decomposition, especially in less fertile soils. Microbiome 2021;9(1):84; doi:10.1186/s40168-021-01032-x.

40. Jayasekara S, Ratnayake R. Microbial cellulases: an overview and applications. Cellulose 2019; doi:10.5772/intechopen.84531.

41. Passos D. de F, Pereira N, Castro A M de. A comparative review of recent advances in cellulases production by Aspergillus, Penicillium and Trichoderma strains and their use for lignocellulose deconstruction. Curr Opin Green Sustainable Chem 2018;14:60-6; doi:10.1016/j. cogsc.2018.06.003.

42. Bettache A, Zahra A, Boucherba N, Bouiche C, Hamma S, Maibeche $\mathrm{R}$, et al. Lignocellulosic biomass and cellulolytic enzymes of actinobacteria. SAJ Biotechnol 2018;5:203.

43. Hamed MB, Anne J, Karamanou S, Economou A. Streptomyces protein secretion and its application in biotechnology. FEMS Microbiol Lett 2018;365(22); doi:10.1093/femsle/fny250.

\section{How to cite this article:}

Sudarshan A, Renuka S, Reshma S, Shilanjali B, Agsar D. Upsurge production of cellulase from maize stover under soildstate conditions mediated by Streptomyces enissocaesilis DQ026641. J Appl Biol Biotech 2022; 10(01):136-144. 